\title{
How do they deal with the Pandemic? The effect of secure attachment and mindfulness on adolescent resilience
}

\author{
Dewi Khurun Aini, ${ }^{1 *}$ Marcus Stück, ${ }^{2}$ Lucky Ade Sessiani, ${ }^{1}$ Darmuin ${ }^{1}$ \\ ${ }^{1}$ Faculty of Psychology and Health, Universitas Islam Negeri Walisongo, Semarang - Indonesia, \\ ${ }^{2}$ DPFA Academy of Work and Health, Leipzig - Germany
}

\begin{abstract}
Building resilience in adolescents is an important need, especially for those who spend most of their time at home with their families while facing the pandemic situation. Resilience enables adolescents to survive, adapt, and rise up when faced with difficult circumstances. This study aims to empirically examine the role of secure attachment and mindfulness in adolescent resilience in the new normal era. The study subjects were 220 junior high school students in Semarang City, Indonesia, who were selected using the convenience sampling technique. The study is based on correlational quantitative research using regression analysis. The instruments used were the Secure Attachment Scale, Mindfulness Scale, and Resilience Scale. The results show that there was a significant and positive relationship between secure attachment and mindfulness, and adolescent resilience in the new normal era $\left(\mathrm{R}^{2}=.56, \mathrm{~F}=16169\right.$, $\mathrm{p}<.01$ ). The findings provide useful suggestions for families to emphasize the development of psychological skills, especially resilience in adolescents, throughout the country.
\end{abstract}

Keywords: secure attachment; mindfulness; adolescent resilience

\begin{abstract}
Abstrak: Membangun ketahanan pada remaja merupakan kebutuhan yang sangat besar, terutama bagi remaja yang menghabiskan sebagian besar waktunya di rumah bersama keluarga sekaligus berusaha mengatasi situasi pandemi. Resiliensi memungkinkan remaja untuk bertahan, beradaptasi, dan bangkit ketika menghadapi keadaan sulit. Penelitian ini bertujuan untuk menguji secara empiris peran secure attachment dan mindfulness terhadap resiliensi remaja di era New Normal. Subjek penelitian ini adalah 220 remaja siswa SMP di Kota Semarang yang dipilih dengan teknik convenience sampling. Penelitian ini merupakan penelitian kuantitatif korelasional dengan menggunakan analisis regresi. Instrumen yang digunakan dalam penelitian ini adalah Skala Secure Attachment, Skala Mindfulness, dan Skala Resiliensi. Hasil penelitian menunjukkan adanya hubungan yang signifikan dan positif antara secure attachment dan mindfulness dengan resiliensi remaja di era New Normal $(\mathrm{R} 2=0,56, \mathrm{~F}=16169, \mathrm{p}<0,01)$. Oleh karena itu, hasil ini menjadi saran yang berguna bagi keluarga untuk menekankan pada pengembangan keterampilan psikologis khususnya ketahanan pada remaja di seluruh tanah air.
\end{abstract}

Kata Kunci: kelekatan aman; mindfulness; resiliensi remaja

\footnotetext{
*Corresponding Author: Dewi Khurun Aini (dewi_khurun@walisongo.ac.id), Faculty of Psychology and Health, Universitas Islam Negeri Walisongo, Jl. Prof. Dr. HAMKA, Km. 2 Ngaliyan Semarang 50185-Indonesia.
} 


\section{Introduction}

Families are life-long educators of children and adolescents. Adolescents are active learners, passing through critical moments of identityseeking, unique from one another in developing their full potential (Santrock, 2003; Sarwono, 2011; Yusuf, 2009). They face many changes that may result in stress and negative impacts on relationships and behavior, such as conflicts with parents, emotional changes, and the emergence of risky behavior. Disobeying and rebelling against parents, juvenile delinquency and drug use are some of the forms of such behavior (Utami \& Helmi, 2017).

Resilience is an increasingly important topic for children, adolescents, students, parents, educators, schools, and the community as a result of the COVID-19 pandemic that started in early 2020. Families with teenage children have faced many challenges during the pandemic. The development of a sedentary lifestyle resulting from the increased use of digital platforms, and the many social changes taking place, mean that parents and teenagers are struggling to survive in the new order era. The ability to endure difficult circumstances and strive to learn and adapt, look for solutions, and be steadfast, tough, and persistent is called resilience.

It is the ability to rise above negative experiences or risky situations and even become stronger during the process (Hague \& Mullender, 2006; Masten \& Gewirtz, 2006; Reivich \& Shatté, 2002). Resilient individuals are able to show positive results in their development and continue to function positively in risky situations (Masten \& Gewirtz, 2006); they can negotiate with life development crises and continue to function adequately (Bukhori, Hassan, Hadjar, \& Hidayah, 2017); and are also able to develop new coping skills (Grothberg, 1995). Furthermore, resilient individuals can bounce back after traumatic situations (Azzahra, 2017), attempt to return to their initial achievements and even exceed them after experiencing a downturn (Masten \& Gewirtz, 2006; Reivich \& Shatté, 2002). The key factors involved in resilience can be seen in the scheme in Figure 1.

The key to resilience is the individual mindset, the positive attitude of the individual is facing difficulties, the drive to rise, the style of thinking, and individual belief in the difficulties being faced as something positive (Reivich \& Shatté, 2002).

\section{Figure}

Key Factors in Resilience

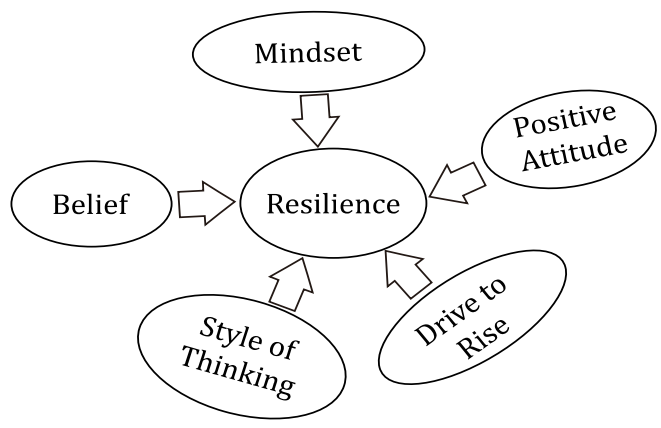


According to data from the COVID-19 Task Force from July 2020, the pandemic is prone to result in emotional distress in children and adolescents, such as excessive fear and boredom. Distance learning can also carry the risk of mental health problems for them. Previous studies have found that $37 \%$ of children and adolescents cannot manage their learning time, $30 \%$ have difficulty understanding lessons, and $21 \%$ do not understand teachers' instructions (Guessoum et al., 2020).

Based on previous research, several variables affect resilience (Indirasari et al., 2019), including social support, self-efficacy, and mindfulness (Keye \& Pidgeon, 2013; Raisa \& Ediati, 2017; Ruswahyuningsi \& Afiatin, 2015; Utami \& Helmi, 2017). There is a significant relationship between mindfulness and quality of life. When individuals are mindful, their tendency to experience depression is lower (Fourianalistyawati et al., 2016).

Mindfulness basically means paying attention to one's environment with openness, curiosity, and flexibility. In a conscious state, complex thoughts and feelings have much less impact and influence on behavior (Kashdan \& Ciarrochi, 2013). Mindfulness involves being aware of experiences over time in a clear and balanced manner. That is, being open to current reality, and allowing all thoughts, emotions, and sensations to enter consciousness without resistance or avoidance (Neff \& Germer, 2018). Therefore, part of mindfulness is "together with" the self as it is, fully aware, fully present, and not mindless (Arif, 2016; Langer, 2016; Lopez, 2009; Marotta, 2013).

Mindfulness counters the tendency to avoid painful thoughts and emotions, enabling indivi- duals to face the truth of experiences, even when they feel unpleasant. At the same time, it prevents individuals from absorbing and recognizing excessive negative thoughts or feelings, so not allowing them to be trapped and carried away by aversive reactions (Neff \& Germer, 2018). According to Langer (2016), there are four aspects of mindfulness: (1) viewing a situation from several perspectives; (2) seeing the information presented in the situation as new; (3) paying attention to the context in which individuals receive information; and (4) creating new categories in which this information can be understood. Furthermore, in a mindful state, individuals direct their lives with intention, so can focus on their real personality and life, and not lose themselves in unimportant things (Marotta, 2013).

In this study, mindfulness was used as a predictor, related to individual internal factors. It concerns paying attention in a certain way, and focusing on one thing deliberately, right now, without judging or making judgments. Mindfulness involves several phases, including observing, describing, being aware of actions, not judging, and being non-reactive (Brown \& Ryan, 2003; Baer et al., 2008).

Many studies have suggested that the availability of certain protective factors can help to deal with the detrimental effects of negative life events. Anapratiwi et al. (2013) state that children who have safe attachment to their mother will have good social skills, find it easier to make friends, have healthy relationships, and adapt easily to the social environment, because they believe the environment they live in can provide comfort and security. 
Bowlby divides attachment into secure attachment and insecure attachment, with the former characterized by children who have selfesteem and a positive view of others (Bowlby, 1988). Secure attachment constitutes an important psychological basis for building relationships with others, allowing people to understand others' emotions and be more empathetic (Nie et al., 2016). It also helps children to learn to develop social skills such as empathy, emotional sensitivity, and understanding of what other people want from them (Aryanti, 2015). Individuals who have secure attachment feel more comfortable with intimacy and interdependence, making it easier for them to consider others deserving of closeness, sympathy, and mutual support, thus creating a positive self-model (Cassidy \& Shaver, 2017; Shaver et al., 2019). During the pandemic, adolescents have needed to return to the role and function of the family, which refers to behaving and acting in response to the conditions. Any anxiety, worry or feelings of insecurity felt by adolescents will be responded to appropriately if the family is functioning properly.

There are many types of physical and psychological changes experienced by adolescents, so the variable of resilience is important for those facing problems during the pandemic. Based on the descriptions and phenomena above, the researchers are interested in further examining the effect of mindfulness and secure attachment on adolescent resilience in the New Normal Era.

There are three hypotheses in the research: 1) mindfulness has an influence on adolescent resilience in the post-pandemic period; 2) there is a relationship between secure attachment and adolescent resilience in the post-pandemic period; and 3) mindfulness and secure attachment have an influence on adolescent resilience in the postpandemic period.
The study aims to empirically test the role of secure attachment and mindfulness in adolescent resilience in the New Normal Era, specifically among adolescents studying at junior high school in the city of Semarang. The research sample election was based on the representation of the conditions of urban adolescent students.

\section{Method}

The study participants were 220 junior high school students aged 13-16, from the urban area of Semarang city. The sampling method was nonprobability sampling employing a convenience sampling technique. Before the data collection, the author informed the participants about the research objectives. Descriptive data on subjects is presented in Table 1.

The research instrument used a resilience scale, a secure attachment scale and a mindfulness scale. The three scales were tested on 40 trial respondents before being used for the research.

The resilience of the adolescents was measured using a Resilience Scale compiled by researchers based on the theory of Reivich and Shatté (2002) consisting of seven factors, namely emotional regulation, impulse control, optimism, empathy, analysis of the causes of problems, selfefficacy, and reaching out. There were 42 items before the trial, none of which failed, with the corrected total item correlation score ranging between 0.376 and 0.788 and a Cronbach's alpha score of 0.938 .

The second instrument was a safe attachment scale developed from Ainsworth's theory (Ainsworth, 1978), consisting of the aspects of a warm attitude in dealing with other people; being not too dependent on others; not avoiding 
Table 1

Demographic Research Subject Data

\begin{tabular}{llll}
\hline Number of students & $\begin{array}{l}\text { Junior High } \\
\text { School (SMP) }\end{array}$ & $\begin{array}{l}\text { Islamic Junior } \\
\text { High School }\end{array}$ & Total \\
\hline Male & 52 & 40 & 92 \\
Female & 75 & 53 & 128 \\
Total & & & 220 \\
\hline
\end{tabular}

Table 2

Results of the Reliability and Validity of the Measurement Instrument

\begin{tabular}{ll}
\hline Scale & Reliability (Cronbach's alpha) \\
\hline Mindfulness & .842 \\
Secure Attachment & .943 \\
Resilience & .938 \\
\hline
\end{tabular}

other people; being very close to the people one loves; being empathetic towards others; highly trusting loved ones, and being more comfortable with that one love. Before the trial, the number of items on this scale was 36 . The discrimination index based on the corrected item-total correlation score ranged between .351 and .749, with a Cronbach's alpha score of 943.

The mindfulness scale was adapted from the Child and Adolescent Mindfulness Measure (CAMM) scale (Baer et al., 2006, 2008). This scale consisted of items that measured three components of mindfulness in adolescents, namely acting with awareness, observing, and accepting without judgment. All the items on the scale were unfavorable ones, so the scoring was based on a Likert scale ranging from $0=$ Always to $4=$ Never. An example of a scale item was: "It is difficult for me to pay attention to only one thing at a time".

The CAMM scale trial was conducted on 40 adolescents. Before the trial, the number of items on the scale was 32 , and none of them failed after being tested. The discrimination index based on the corrected item-total correlation score ranged between .374 and .791, with a Cronbach's alpha score of .842. Based on the reliability calculations, the level of consistency of the measuring instruments is presented in Table 2.

\section{Research Variable Theory Framework Scheme}

The variable scheme discussed in this study is shown in the figure 2 .

\section{Data Analysis}

The data obtained were analyzed through multiple regression analysis to determine the relationship between and role of the positive attachment variables, mindfulness, and adolescent resilience. The data analysis was statistically aided by SPSS 24 for Windows. Before testing the hypothesis, the researcher first conducted des criptive statistical and classical assumption tests. 
Figure 2

Research Variable Theory Framework Scheme

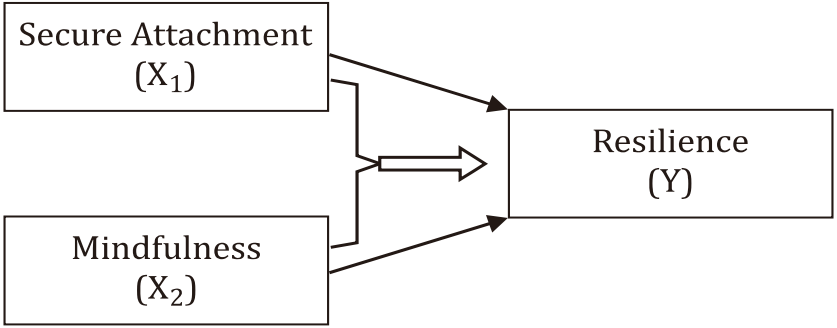

The former comprised a normality test, multicollinearity test, and heteroscedasticity test. In the hypothesis testing, the data analysis method used was a multiple regression test. Multiple regression analysis aims to determine whether or not there is an influence of two or more independent variables $(\mathrm{X})$ on the dependent variable (Y).

\section{Results}

Exposure to research data, a regression test was conducted to determine the role of secure attachment and mindfulness on resilience in adolescents.

Before testing the hypothesis, the researcher first performed the classical assumption tests, namely a normality test, multicollinearity test, and heteroscedasticity test. The KolmogorovSmirnov test showed a significant result of .08 ( $p>$.05), so it can be concluded that the data were distributed normally.

The results of the linear secure attachment test with resilience are indicated by $\mathrm{p}<0.01$, while the significance value of the deviation from linearity is $\mathrm{p}=.854(>.05)$. The linear mindfulness test results show resilience with $\mathrm{p}=$
$<0.01$, and the significance value in the deviation from the linearity column is $p=.674(>0.05)$. The results show that both the independent variables, secure attachment and mindfulness, have a linear relationship with resilience.

As shown in Table 4, the regression analysis resulted from variable $X_{1}$ against $Y$ with a value of $\mathrm{p}<.01$ and a t-count value of $65.863>$ t-table 1.962. In addition, the t-count variable $X_{2}$ to $Y$ had a p-value of $.029<.05$ and a t-count value of $2.199>$ t-table 1.962. The results show a significant and positive relationship between secure attachment and mindfulness and youth resilience in the New Normal Era.

The hypothesis analysis showed the effect of $\mathrm{X}_{1}$ (secure attachment) on $\mathrm{Y}$ (resilience) to be equal to $\mathrm{p}<0.01$ and the $\mathrm{t}$ count value to be 65.863 > t-table 1.962, so $\mathrm{H}_{1}$ was accepted, which means that there is an effect of $X_{1}$ (secure attachment) on $\mathrm{Y}$ (resilience). Hypothesis analysis for the effect of $\mathrm{X}_{2}$ (mindfulness) on $\mathrm{Y}$ (resilience) showed that $\mathrm{p}=.029<.05$ and that the $\mathrm{t}$-value was 2.199> t-table 1.962 , so $\mathrm{H}_{2}$ can also accepted, which means that there is an effect of $\mathrm{X}_{2}$ (mindfulness) on $\mathrm{Y}$ (resilience). 
Table 3

Descriptive Data of the Research Results

\begin{tabular}{llll}
\hline & Resilience & Secure Attachment & Mindfulness \\
\hline $\mathrm{N}$ & 220 & 220 & 220 \\
Empirical Mean & 84.56 & 77.63 & 93.93 \\
$\mathrm{SD}$ & 9.014 & 6.043 & 15.407 \\
Min & 65 & 65 & 70 \\
Max & 120 & 90 & 120 \\
Low Category & $54(24.5 \%)$ & $45(20.5 \%)$ & $36(16.4 \%)$ \\
Medium Category & $124(56.4 \%)$ & $112(50.9 \%)$ & $103(46.8 \%)$ \\
High category & $42(19.1 \%)$ & $63(28.6 \%)$ & $81(36.8 \%)$ \\
\hline
\end{tabular}

Table 4.

Multiple Regression Test Results: Beta Coefficient Value

\begin{tabular}{|c|c|c|c|c|c|}
\hline & \multicolumn{2}{|c|}{$\begin{array}{c}\text { Unstandardized } \\
\text { Coefficients }\end{array}$} & \multirow{2}{*}{$\begin{array}{c}\begin{array}{c}\text { Standardized } \\
\text { Coefficients }\end{array} \\
\text { Beta } \\
\end{array}$} & \multirow[t]{2}{*}{$\mathrm{T}$} & \multirow[t]{2}{*}{ Sig. } \\
\hline & $\mathrm{B}$ & Std. Error & & & \\
\hline 1 (Constant) & -.283 & 1.248 & & -.227 & .821 \\
\hline Mindfulness & .979 & .015 & .967 & 65.863 & .000 \\
\hline Secure Attachment & .028 & .013 & .032 & 2.199 & .029 \\
\hline
\end{tabular}

Dependent Variable: Resilience

Table 5

Multiple Regression Test Results: Significance of the F Value

\begin{tabular}{lllllll}
\hline Model & & Sum of Squares & $\mathrm{df}$ & Mean Square & $\mathrm{F}$ & Sig. \\
\hline 1 & Regression & 7330.358 & 2 & 3665.179 & 16169.543 & $.000 \mathrm{~b}$ \\
& Residual & 49.188 & 217 & .227 & & \\
& Total & 7379.545 & 219 & & & \\
\hline
\end{tabular}

a. Dependent Variable: Resilience

b. Predictors: (Constant), Mindfulness, Secure Attachment

Table 6

Multiple Regression Test Results: R-Value

\begin{tabular}{lllll}
\hline Model & $\mathrm{R}$ & $\mathrm{R}$ Square & Adjusted R Square & Std. Error of the Estimate \\
\hline 1 & $.595^{\mathrm{a}}$ & .568 & .560 & 1.14781 \\
\hline aPredictors: (Constant), Mindfulness, Secure Attachment &
\end{tabular}

Based on the result shown in Table 5, the significance value for the effect of $X_{1}$ and $X_{2}$ simultaneously on $\mathrm{Y}$ was equal to $\mathrm{p}<.01$ and the calculated F-value was 16169,543> F-table 1,65251 , so the third hypothesis is also accepted, which means that there is an influence of $\mathrm{X}_{1}$ (secure attachment) and $\mathrm{X}_{2}$ (mindfulness) simultaneously on $\mathrm{Y}$ (resilience).

Table 6 described the R-value or the regression coefficient at .595 , while the $\mathrm{R}$ square 
$\left(R^{2}\right)$ had a coefficient of determination of .568. The adjusted $\mathrm{R}^{2}$ value indicates roles or contributions are both independent variables, namely mindfulness and secure attachment, with respect to the dependent variable, namely adolescent resilience, in a regression test involving more than two variables. The results of the multiple regression tests between the independent and dependent variables indicate that mindfulness and secure attachment simultaneously contribute to youth resilience at the level of $56.8 \%$, while other factors determine the remaining $43.2 \%$.

The results of the study indicate that secure attachment and mindfulness have a significant effect on adolescent resilience. The results of this hypothesis test show a value of 3,987> F-table 1,65251 with a significance level of $\mathrm{p}<.05$, namely $\mathrm{p}=0.02$ [significant]. The level of the influence of secure attachment and mindfulness on adolescent resilience was $56.8 \%$, with the remaining $43.2 \%$ influenced by other predictive factors.

\section{Discussion}

Based on the results of multiple regression analysis, the research hypotheses are accepted. Both predictors, secure attachment, and mindfulness, play a role in the formation of adolescent resilience in the new normal period. This is based on the $\mathrm{R}$ coefficient of the regression test results of 0.568 , and the significance value of the F-test of 0.000. The study results support previous research, which found that students with high mindfulness make more efforts to lead a quality life and be able to rise from the adversity they face (Fourianalistyawati et al., 2016; Neff \& Germer, 2018).

Research by Asmariza et al. (2019) found that the dominant role of parents and family as attachment figures acts as the main social environment for children and the place where they receive protection, love, affection, security, and attachment. Parents consistently and responsively provide affection and support for children in them becoming resilient individuals (Maentiningsih, 2008).

Good mindfulness and secure attachment will improve resilience ability. Individuals who have mindfulness and safe attachment will be able to try to use their awareness and continue to focus on overcoming the problems at hand. Moreover, when individuals have safe attachment, they will gain a sense of confidence to overcome the problems they are facing, have empathy, as well as good social relations, which is what adolescents need in dealing with conditions during the pandemic. Individuals who have high resilience are able to maintain positive feelings, optimism, understanding of self-control, and selfconfidence related to problem-solving efforts.

Mindfulness has been proven to be effective for adolescents, including reducing stress (Maharani, 2013), and it can improve their psychological wellbeing and quality of life (Brown et al., 2007; Brown \& Ryan, 2003; Hasanudin et al., 2019; Savitri \& Listiyandini, 2017).

In this research, most of the adolescents (56.4\%) show resilience scores in the medium category, as is the case for the values of secure attachment (50.9\%), and those for mindfulness (46.8\%). Therefore, this shows that the resilience scores synergize with those for secure attachment and mindfulness amongst the adolescent subjects.

Attachments serve as a form of defense and meet the need for security. The feeling of security that results from secure attachment has a close 
relationship with the ability to develop creativity and exploration (to control the environment), as well as with resilience and the growth of individuals who are healthy and have healthy social relationships (Holmes, 1993). Adolescent attachment to parents (family) can help them develop social competence and social welfare (Santoso, 2011; Santrock, 2003). Those who have secure attachment also show more positive emotional development (Purnama \& Wahyuni, 2017), have greater empathy and are more able to learn lessons. Mindfulness in psychology research concerns overcoming mental and physical illness (Jain et al., 2007), while mindfulness training can be used as a preventive intervention, namely dispositional mindfulness (Brown \& Ryan, 2003), to increase mindfulness, reduce the rejection of experiences and negative feelings, and increase mindfulness ability in decentering (Tanay et al., 2012).

It has been demonstrated in this study that mindfulness involves the quality of concentration of attention and that of awareness, which is in accordance with previous research (Kabat-Zinn, 2003). Mindfulness represents the main human ability, and refers to knowledge and attention towards every condition that occurs, including attention and awareness (Brown et al., 2007).

The level of mindfulness of adolescents can be seen from the results of the scale based on the theory of Baer et al. the mindfulness scale used was an adaptation of the Child and Adolescent Mindfulness Measure (CAMM) scale (Baer et al, 2006; Baer et al., 2008), with four aspects of mindfulness, namely observation, description, acting with awareness, and acceptance without judging. The level of mindfulness of adolescents during the pandemic can be seen from the results of the mindfulness scale, which were as expected; the higher the score obtained on the mindfulness scale, the higher the adolescent's mindfulness, and conversely, the lower the score, the lower the mindfulness. The resilience aspects in this research instrument were emotional regulation, impulse control, optimism, empathy, analysis of causes of problem, self-efficacy, and reaching out (Reivich \& Shatté, 2002). There are two skills in resilience that help individuals to control otherwise uncontrollable emotions, namely calming and focusing, which are also useful in terms of maintaining the focus of the individual's mind and reducing stress experienced by them. It should be highlighted that the skill of resilience consists of the aspects of emotion regulation and involved mindfulness.

This research may be applied to develop mindfulness, supported by the attachment of safe parental social support (secure attachment). This implementation is expected to be effective for adolescents who are still at junior high school. Especially in this New Normal Era, the welfare of children and adolescents becomes a shared responsibility, including how to develop strategies to improve resilience. Adolescent resilience emphasizes more the ability to rise up from difficulties faced, adapt to the pressures and problem that arise, and develop competencies (social, academic, and daily school assignments) where thus needs to be done well. The two steps involved are mitigation (minimizing the impact of risk) and the development of resilience.

Mitigation, or minimizing the impact of risk in the lives of adolescents, can be achieved in various ways, namely (1) by increasing positive closeness between them, positive parenting, assertive communication, and good patterns of 
interaction between family members; (2) by establishing clear and consistent boundaries; (3) and by teaching life skills, including the ability to work together, to develop healthy conflict resolution, resistance and assertiveness skills, communication skills, problem-solving, and decision making, as well as healthy stress coping management. In addition, efforts to develop resilience first include the attention and support given by parents. Acceptance and strengthening are needed by children today, not only from nuclear family members, but from anyone who has a close relationship with them. Second, parents should organize and communicate realistic and realistic expectations for the future, which are effective motivators for children and adolescents. Third, parents should provide opportunities for adolescents to develop their potential, giving them the responsibility to participate in daily tasks, with the aim that children and adolescents learn to solve problems, make decisions, make plans, set targets, and learn to help others according to their abilities, so that over time this will increase the positive selfconcept in adolescents. All these skills will consistently be critical factors that determine the development of adolescent resilience (Henderson \& Milstein, 2003). Fourth, a healthy environment should be provided for growth and development, including good examples that children can access at any time as a reference for their behavior. Fifth, attention should be paid to growth and continuing to strengthen children's internal protective factors, such as independence, emotional maturity, self-determination, and communication. Sixth, children should be trained to be able to manage various risks in their social interactions independently, and finally, they should be trained to master coping and positive adaptation.

At this stage, individuals are expected to be able to bring back and be aware of experiences that made them uncomfortable previously, which will provide important information for them concerning the next steps in their plans, whether to change or continue to display the same state of behavior. This step can help individuals to begin to catch thoughts that are not realistic or ones that do not correspond to them. In a mindful state, the individual presents feelings, sensations, and affective conditions, and identifies the feelings that are present, and where they are located in the body. This creates a space of acceptance for uncomfortable feelings and sensations, with which individuals begin to make peace and be able to rise above the situation and take lessons from previous stressful events, meaning they achieve happiness with the people they care about.

\section{Conclusion}

The study findings reveal that secure attachment and mindfulness have a very significant effect on adolescent resilience. The results also show that secure attachment and mindfulness are correlated to adolescent resilience. There is a positive correlation between the dependent variable and both independent variables, which implies that if adolescents have a positive attachment to their parents and families and possess high skills of self-awareness and mindfulness, they will be more resilient. As shown in Table 3, most of the adolescents in the study (56.4\%) had resilience scores in the medium category, with those for secure attachment also mostly in the same category (50.9\%), as was the case for 
mindfulness (46.8\%). The similar scores for all the variables show synergy and intercorrelation that may result in a simultaneous impact. Increasing secure attachment and mindfulness will result in high resilience.

The findings suggest that parents and families should be more aware of their relationship with their adolescent children and encourage them to practice mindfulness, as both may increase resilience. Adolescents with secure attachment and mindfulness will be most likely to experience well-being and highly resilient. If they increase their secure attachment to their parents and families and are more fully aware of themselves (are mindful), their adaptability and resistance in difficult situations, namely their resilience, will increase. Parents may need to reflect, re-evaluate and re-attach to their children in order to develop a healthy relationship and boost adolescents' self-esteem, happiness, and well-being.

Based on the results of the study, it is suggested that research related to resilience should be conducted in a sustainable manner so that it can provide benefits and contribute to the problems faced by society in the New Normal Era. This research also emphasizes that it is important to develop positive psychological characteristics in order to increase the adversity quotient and improve the quality of life during uncertain circumstances such as a pandemic.

Despite the valuable findings, this research has some limitations. The research sample was limited in number and characteristics, which may impact on its representativeness of the broad population of adolescents. In further research, samples from different levels of education, or various age ranges, would provide more inclusive descriptions. The regression analysis in this research only provided estimation of the correlation and impact among dependent and two independent variables, but there is no comparison between different groups of subjects. Future research could focus on different groups and estimate the effect size. Experimental research with a control group is strongly suggested.[]

\section{References}

Ainsworth, M. D. S. (1978). Patterns of attachment: A psychological study of the strange situation. Lawrence Erlbaum Associates.

Anapratiwi, D., Handayani, S. S. D., \& Kurniawati, Y. (2013). Hubungan antara kelekatan anak pada ibu dengan kemampuan sosialisasi anak usia 4-5 tahun (Studi pada RA Sinar Pelangi dan RA Al Iman Kecamatan Gunungpati, Semarang). Early Childhood Education Papers (Belia), 2(1), 2330.https://doi.org/10.15294/BELIA.V2I1.2243

Arif, I. S. (2016). Psikologi positif: Pendekatan saintifik menuju kebahagiaan. Gramedia Pustaka Utama.

Aryanti, Z. (2015). Kelekatan dalam perkembangan anak. Jurnal Tarbawiyah, 12(2), 245-258.

Asmariza, W., Chairilsyah, D., \& Puspitasari, E. (2019). Hubungan kelekatan aman (secure attachment) dengan resiliensi anak usia 5-6 tahun di TK Negeri Pembina 3 Kecamatan Marpoyan Damai Kota Pekanbaru. Jurnal Online Mahasiswa Fakultas Keguruan Dan Ilmu Pendidikan, 6(2).

Azzahra, F. (2017). Pengaruh resiliensi terhadap distres psikologis pada mahasiswa. Jurnal Ilmiah Psikologi Terapan, 5(1), 80-96. https://doi.org/10.22219/jipt.v5i1.3883 
Baer, R. A., Smith, G. T., Hopkins, J., Krietemeyer, J., \& Toney, L. (2006). Using self-report assessment methods to explore facets of mindfulness. Assessment, 13(1), 27-45. https://doi.org/10.1177/1073191105283504

Baer, R. A., Smith, G. T., Lykins, E., Button, D., Krietemeyer, J., Sauer, S., Walsh, E., Duggan, D., \& Williams, J. M. G. (2008). Construct validity of the Five Facet Mindfulness Questionnaire in meditating and nonmeditating samples. Assessment, 15(3), 329-342. https://doi.org/10.1177/1073191107313003

Bowlby, J. (1988). A secure base: Parent-child attachment and healthy human development. Basic Books.

Brown, K. W., \& Ryan, R. M. (2003). The benefits of being present: Mindfulness and its role in psychological well-being. Journal of Personality and Social Psychology, 84(4), 822-848. https://doi.org/10.1037/0022-3514.84.4.822

Brown, K. W., Ryan, R. M., \& Creswell, J. D. (2007). Mindfulness: Theoretical foundations and evidence for its salutary effects. Psychological Inquiry, 18(4), 211-237. https://doi.org/10.1080/10478400701598298

Bukhori, B., Hassan, Z., Hadjar, I., \& Hidayah, R. (2017). The effect of sprituality and social support from the family toward final semester university students' resilience. Man in India, 97(19), 313-321.

Cassidy, J., \& Shaver, P. R. (2017). Handbook of attachment: Theory, research, and clinical applications. Guilford Press.

Fourianalistyawati, E., Listiyandini, R. A., \& Fitriana, T. S. (2016). Hubungan mindfulness dan kualitas hidup orang dewasa. Prosiding Forum Ilmiah Psikologi Indonesian (FIPI), 1-12.

Grothberg, E. (1995). A guide to promoting resilience in children: Strengthening the human spirit. Early childhood development: Practice and reflections (No. 8). Benard van Leer Foundation.

Guessoum, S. B., Lachal, J., Radjack, R., Carretier, E., Minassian, S., Benoit, L., \& Moro, M. R. (2020). Adolescent psychiatric disorders during the COVID-19 pandemic and lockdown. Psychiatry Research, 291, 113264. https://doi.org/10.1016/j.psychres.2020.113264

Hague, G., \& Mullender, A. (2006). Who listens? The voices of domestic violence survivors in service provision in the United Kingdom. Violence Against Women, 12(6), 568-587. https://doi.org/10.1177/1077801206289132

Hasanudin, R. J. B., Siswandi, A. G. P., \& Wardhani, N. (2019). Mindfulness-Based Cognitive Therapy (MBCT) in improving quality of life: Case study in Chronic Kidney Disease patients with hemodialysis. Psikohumaniora: Jurnal Penelitian Psikologi, 4(1), 13-26. https://doi.org/ 10.21580/pjpp.v4i1.3332

Henderson, N., \& Milstein, M. M. (2003). Resiliency in schools: Making it happen for students and educators. Corwin Press.

Holmes, J. (1993). John Bowlby and attachment theory. Routledge.

Indirasari, D. T., Purba, D. E., \& Anindita, R. (2019). Future time perspective and turnover intention: The mediating role of resilience. Psikohumaniora: Jurnal Penelitian Psikologi, 4(1), 1-12. https://doi.org/10.21580/pjpp.v4i1.3120

Jain, S., Shapiro, S. L., Swanick, S., Roesch, S. C., Mills, P. J., Bell, I., \& Schwartz, G. E. R. (2007). A randomized controlled trial of mindfulness meditation versus relaxation training: Effects on distress, positive states of mind, rumination, and distraction. Annals of Behavioral Medicine, 33(1), 1121.https://doi.org/10.1207/s15324796abm3301_2 
Kabat-Zinn, J. (2003). Mindfulness-based interventions in context: Past, present, and future. Clinical Psychology: Science and Practice, 10(2), 144-156. https://doi.org/10.1093/clipsy.bpg016

Kashdan, T. B., \& Ciarrochi, J. (Eds.). (2013). Mindfulness, acceptance, and positive psychology: The seven foundations of well-being. New Harbinger Publications.

Keye, M. D., \& Pidgeon, A. M. (2013). Investigation of the relationship between resilience, mindfulness, and academic self-efficacy. Open Journal of Social Sciences, 1(6), 1-4. https://doi.org/10.4236/jss.2013.16001

Langer, E. J. (2016). The power of mindful learning. Da Capo Press.

Lopez, S. J. (2009). The encyclopedia of positive psychology. In The encyclopedia of positive psychology. Blackwell Publishing.

Maentiningsih, D. (2008). Hubungan antara secure attachment dengan motivasi berprestasi pada remaja. Universitas Gunadarma.

Maharani, E. A. (2013). Pengaruh pelatihan "meditasi sadar diri" terhadap penurunan tingkat distres remaja yang mengalami kehamilan pranikah. Universitas Gadjah Mada.

Marotta, J. (2013). 50 mindful steps to self-esteem : Everyday practices for cultivating self-acceptance and self-compassion. New Harbinger Publications.

Masten, A. S., \& Gewirtz, A. H. (2006). Resilience in development: The importance of early childhood. In Encyclopedia on early childhood development. Centre of excellence for early childhood development.

Neff, K., \& Germer, C. (2018). The mindful self-compassion workbook: A proven way to accept yourself, build inner strength, and thrive. Guilford Publications.

Nie, Y.-G., Li, J.-B., \& Vazsonyi, A. T. (2016). Self-control mediates the associations between parental attachment and prosocial behavior among Chinese adolescents. Personality and Individual Differences, 96(36), 36-39. https://doi.org/10.1016/j.paid.2016.02.077

Purnama, R. A., \& Wahyuni, S. (2017). Kelekatan (attachment) pada ibu dan ayah dengan kompetensi sosial pada remaja. Jurnal Psikologi, 13(1), 30-40.

Raisa, R., \& Ediati, A. (2017). The relationship between social support and resilience in inmates in Class IIA Women's Penitentiary Semarang. Jurnal Empati, 5(3).

Reivich, K., \& Shatté, A. (2002). The resilience factor: 7 essential skills for overcoming life's inevitable obstacles. Broadway Books.

Ruswahyuningsi, M. C., \& Afiatin, T. (2015). Resiliensi pada remaja Jawa. Gadjah Mada Journal of Psychology, 1(2), 96-105. https://doi.org/https://doi.org/10.22146/gamajop.7347

Santoso, S. W. (2011). Keterlibatan, keberhargaan, dan kompetensi sosial sebagai prediktor kompetisi pada remaja. Jurnal Psikologi, 38(1), 52-60. https://doi.org/10.22146/jpsi.7664

Santrock, J. W. (2003). Adolescence: Perkembangan remaja (S. B. Adelar (Trans.)). Erlangga.

Sarwono, S. (2011). Psikologi remaja. RajaGrafindo Persada.

Savitri, W. C., \& Listiyandini, R. A. (2017). Mindfulness dan kesejahteraan psikologis pada remaja. Psikohumaniora: Jurnal Penelitian Psikologi, 2(1), 43. https://doi.org/10.21580/pjpp.v2i1.1323

Shaver, P. R., Mikulincer, M., \& Cassidy, J. (2019). Attachment, caregiving in couple relationships, and prosocial behavior in the wider world. Current Opinion in Psychology, 25(2), 16-20. https://doi.org/https://doi.org/10.1016/j.copsyc.2018.02.009 
Tanay, G., Lotan, G., \& Bernstein, A. (2012). Salutary proximal processes and distal mood and anxiety vulnerability outcomes of mindfulness training: A pilot preventive intervention. Behavior Therapy, 43(3), 492-505. https://doi.org/10.1016/j.beth.2011.06.003

Utami, C. T., \& Helmi, A. F. (2017). Self-efficacy dan resiliensi: Sebuah tinjauan meta-analisis. Buletin Psikologi, 25(1), 54-65. https://doi.org/10.22146/buletinpsikologi.18419

Yusuf, S. (2009). Psikologi perkembangan anak dan remaja. Remaja Rosdakarya. 